\title{
First record of endoparasitism of Pycnogonida in Hydrozoan polyps (Cnidaria) from the Brazilian coast
}

\author{
Ariane Lima Bettim ${ }^{1,2}$ \& Maria Angélica Haddad ${ }^{1}$ \\ ${ }^{1}$ Departamento de Zoologia, Centro Politécnico, Universidade Federal do Paraná - UFPR, \\ Av. Cel. Francisco H. dos Santos, 210, Jardim das América, CEP 81531-970, Curitiba, PR, Brazil \\ ${ }^{2}$ Corresponding author: Ariane Lima Bettim,e-mail: arianelbt@yahoo.com.br
}

BETTIM, A.L. \& HADDAD, M.A. First record of endoparasitism of Pycnogonida in Hydrozoan polyps (Cnidaria) from the Brazilian coast. Biota Neotrop. 13(2): http://www.biotaneotropica.org.br/v13n2/en/ abstract?short-communication+bn01513022013

\begin{abstract}
Despite the relatively high number of recent studies on Cnidaria off the Brazilian coast, we have observed only two records of parasitism on macromedusae and none on polyps. Endoparasitic associations between Pycnogonida larvae and hydroids have been well known since the early $20^{\text {th }}$ century. Protonymph larvae develop inside the gastrovascular cavity of polyps, typically gastrozooids, which are then called gallzooids. This short communication is an unprecedented record of parasitism on the polyps of Brazilian cnidarian fauna. The parasitic association between Pycnogonida Anoplodactylus stictus and a new hydroid species of Podocoryna has been casually detected on the encrusting communities of experimental polyethylene plates installed at the Paranaguá Yacht Club, Paranaguá, south of Brazil from February 2007 to February 2008. This hydrozoan host is most likely an exotic species because it had not been observed in previous studies of Paranaguá Bay or beaches along the southern coast of Brazil in the previous 20 years. Eighty-eight hydroid colonies were analyzed, of which 19 were parasitized mainly from June to August 2007. Protonymphs were pink-red colored, similar to gallzooids and all other polyps of the colony, thus indicating that they had eaten the hosts' tissues. Up to six protonymphs were observed inside the gallzooids. The gallzooid column was elongated, and the tentacles were atrophied or even absent because of the development of the larvae. Some observations of endoparasitism in two live colonies that were maintained in aquaria until their complete disappearance (one month) are also described in this note. Keywords: benthic community, hydrozoan polyp, interspecific relationship, Pantopoda, protonymph.
\end{abstract}

BETTIM, A.L. \& HADDAD, M.A. Primeiro registro de endoparasitismo de Pycnogonida em pólipos de hidrozoário (Cnidaria) da costa brasileira. Biota Neotrop. 13(2): http://www.biotaneotropica.org.br/v13n2/ pt/abstract?short-communication+bn01513022013

Resumo: Apesar do número relativamente elevado de estudos recentes sobre Cnidaria da costa brasileira, encontramos dois casos de parasitismo, ambos em macromedusas, e nenhum em pólipos. Associações endoparasíticas entre larvas de picnogônidas e hidroides são bem conhecidas desde início do século 20. A larva protoninfa desenvolve-se no interior da cavidade gastrovascular dos pólipos, geralmente dos gastrozoóides, que são então chamados “gallzooids". Esta nota é um registro inédito de parasitismo em pólipos de cnidários da fauna brasileira. A associação parasitária entre o picnogônida Anoplodactylus stictus e uma espécie nova de hidroide do gênero Podocoryna foi detectada casualmente sobre a comunidade incrustante de placas experimentais, instaladas no Iate Clube de Paranaguá, Paranaguá, sul do Brasil, de fevereiro/2007 a fevereiro/2008. O hospedeiro hidrozoário provavelmente é uma espécie exótica, pois não havia sido observado em estudos anteriores da Baía de Paranaguá ou praias ao longo da costa sul do Brasil nos últimos 20 anos. Foram analisadas 88 colônias do hidroide das quais 19 estavam parasitadas, principalmente nos meses de junho a agosto/2007. As protoninfas eram rosa-avermelhadas, a mesma coloração dos "gallzooids" e dos demais pólipos da colônia, indicando que elas ingeriram tecidos do hospedeiro. Até seis protoninfas foram observados no interior dos "gallzooids". O comprimento da coluna dos "gallzooids" alongava e os tentáculos atrofiavam ou mesmo desapareciam devido ao desenvolvimento das larvas. Algumas observações do endoparasitismo em duas colônias vivas mantidas em aquários, até seu desaparecimento completo (um mês), também são descritas nesta nota.

Palavras-chave: comunidade bentônica, hidroide, relação interespecifica, Pantopoda, protoninfa. 


\section{Introduction}

Interspecific relationships between hydrozoan polyps and other marine organisms, such as sponges, bryozoans, molluscs, polychaetes, tunicates and vertebrates (Gili \& Hughes 1995, Puce et al. 2008), include common epibiosis (Cerrano et al. 2001, Gili et al. 2006, Cunha \& Jacobucci 2010) and predation (Madin et al. 1996, Bavestrello et al. 2000, Cerrano et al. 2000) and closer associations, such as commensalism (Hand \& Hendrickson 1950, Braverman 1960, Bavestrello et al. 1996, Genzano \& San Martin 2002), mutualism (Caine 1998, Cerrano et al. 1998, Raskoff \& Robison 2005) and parasitism (Heb \& Melzer 2003).

In parasitic associations, polyps may be the parasite or act as the host (in this short communication, we consider the organism that lives inside a host or has a body part embedded into the host tissues to be the parasite, cf. Boero \& Bouillon (2005)) (Boero et al. 1991, Piraino et al. 1992, Rhode 2005, Evans et al. 2008). Fungi, protozoans and rotifers can be polyp ectoparasites (Gili \& Hughes 1995, Rhode 2005), and Pycnogonida is notable in its ecto- or endoparasitic associations with hydroids (Staples 2005). Pycnogonida/hydroid endoparasitism is characterized by the development of the pycnogonid protonymph inside the gastrovascular cavity of polyps, typically gastrozooids. These parasitized polyps are called gallzooids (Staples \& Watson 1987, Genzano 2002, Heb \& Melzer 2003).

Until the late $20^{\text {th }}$ century, 470 species of Cnidaria had previously been recorded in Brazilian continental and marine waters (Migotto et al. 1999). Currently, this number is approximately 600, with new observations in southeast and southern Brazil (Silveira \& Morandini 2011, Van Ofwegen \& Haddad 2011). From 1997 to 2007, many studies were published on traditional and molecular taxonomy, ecology, toxicity, life cycles and other aspects of this fauna (summary in Haddad \& Marques 2009). This hydrozoan host is most likely an exotic species in Paranaguá Bay, State of Paraná, South of Brazil because it was not observed in previous studies conducted in this location (Correia \& Silva 1990, Neves et al. 2007, Neves \& Rocha 2008). Because the organism was identified as a new species of the genus Podocoryna M. Sars, 1846, the origin of hydroid is unknown. Molecular analysis showed that it is a sister species of $P$. hayamaensis Hirohito, 1988 from Japan (Dr. Maria Pia Miglietta and Dr. Peter Schuchert, pers. comm. The manuscript describing the new species is in preparation; therefore, we refer to it as Podocoryna n. sp. in this paper).

Despite the relatively high number of recent studies, we have observed only two records of parasitism in Brazilian cnidarians, both on macromedusae (Morandini et al. 2005, Nogueira Junior \& Silva 2005). Cases of parasitic relationships with cnidarian polyps have not been observed, although many cases of endoparasitic associations between Pycnogonida larvae and hydroids have been recognized since the early $20^{\text {th }}$ century (Table 1 ). In the majority of these cases, the parasitized species are not uncommon to southeastern and southern Brazilian hydrozoan fauna (Table 1). Therefore, this short communication is an unprecedented record of parasitism on polyps for the cnidarian fauna of Brazil. Some observations of endoparasitism in live colonies are also described.

\section{Material and Methods}

The parasitized hydrozoan colonies were observed within a set of 48 experimental polyethylene plates $(14 \times 14 \mathrm{~cm})$ installed at the marinas of the Paranaguá Yacht Club situated at the Itiberê River mouth $\left(25^{\circ} 31^{\prime} \mathrm{S}\right.$ and $\left.48^{\circ} 30^{\prime} \mathrm{W}\right)$, Paranaguá Bay, State of Paraná, Brazil (Figure 1). The experiment was conducted to study the succession of encrusting species on the artificial plates between
February 2007 and February 2008 (Altvater 2009, Cangussu et al. 2010).

Two polyethylene plates were also collected for tracking parasitized colonies in vivo. Only one Podocoryna n. sp. colony was maintained on the plates, and all other colonies and organisms, except Pycnogonida, were removed. Each plate was placed in separate aquaria with water from the collection site and maintained under constant aeration. The colonies were fed with Artemia salina nauplii approximately three times a week. From one of the plates, the gallzooids of the colony and Pycnogonida adults were removed to establish a control and were referred to as "desparasitized". The other colony was denoted "parasitized". The coverage area of the colonies and each type of zooid (gastro-, gono-, tentaculo- and gallzooids) was estimated under a stereomicroscope using a grid divided into 81 quadrants.

\section{Results}

The Pycnogonida parasite species was identified as Anoplodactylus stictus by the original description of Marcus (1940), and the hydrozoan host was a species of the Podocoryna genus. The hydroid morphology resembled that of Podocoryna carnea (M. Sars, 1846) Hydractiniidae, but the $16 \mathrm{~S}$ rDNA analysis revealed that it was a distinct species (Haddad et al. in preparation).

Fragments of the Podocoryna n. sp. colonies were deposited into the following Cnidaria collections: 1) Museu de Zoologia da Universidade de São Paulo, Brazil (MUZUSP-001908) and 2) Departamento de Zoologia da Universidade Federal do Paraná, Brazil (DZoo-Cn 026). The specimens of Anoplodactylus stictus were also deposited in the Pantopoda collection of the Museu de Zoologia da Universidade de São Paulo, Brazil.

The parasitic association was casually detected on the encrusted communities of the artificial substrata collected in Paranaguá. We observed 88 Podocoryna n. sp. colonies on 28 of the 48 polyethylene plates of the experiment. The colonies were clear-pink, and the polyp hypostomes were highlighted by their whitish color. Nineteen parasitized colonies were distributed on nine plates mainly from June to August 2007. The gallzooids were modified gastrozooids containing one to six protonymphs of A. stictus (Figures $2 \mathrm{a}, \mathrm{b}$ ).

At the initial phase of endoparasitism, the lower section of the gallzooids column appeared slightly dilated and brightly colored. The protonymphs rapidly grew inside the gallzooids and were easily recognizable by their pinkish-red color, thus indicating that they consumed the polyp tissues (Figure 2c). The gallzooids tentacles atrophied or disappeared, whereas their column was elongated and conformed to the number and arrangement of larvae that were concentrated at the bottom or distributed along the column length (Figure 2b). No parasitized gono- or tentaculozooids were observed among the polyps of the Podocoryna n. sp. colonies.

When the two live colonies (one parasitized and one desparasitized) were placed into the aquaria, the parasite larvae were easily visible inside the gallzooids (Figures 2a, b). After eight days, the pinkish colored juveniles emerged with the fourth pair of appendices yet incompletely developed. When the juveniles were released from the gallzooids, no tissues remained inside the polyps, thus demonstrating that they were completely consumed by the parasite. New gallzooids did not appear during the period that the colonies survived in the aquaria (one month).

At the beginning of the observation period, the parasitized and desparasitized colonies had a high density of polyps and covered $8.78 \mathrm{~cm}^{2}$ and $16.3 \mathrm{~cm}^{2}$ of the plates, respectively. The polyps were mainly gastrozooids and covered approximately $70 \%$ of the total area of the colonies (Table 2). 
Endoparasitism in Brazilian Hydrozoan polyps by Pycnogonida

Table 1. Records of the endoparasitism of Pycnogonida larvae in hydroid colonies (Hydrozoa). Classifications cf. the "World Register of Marine Species" (WoRMS, 2012).

\begin{tabular}{|c|c|c|c|}
\hline $\begin{array}{c}\text { Hydroid } \\
\end{array}$ & Pycnogonida & Localities of record & Reference \\
\hline \multicolumn{4}{|l|}{ Subclasse Leptothecata Cornelius, 1992} \\
\hline \multicolumn{4}{|l|}{ Sertulariidae Lamouroux, 1812} \\
\hline Amphisbetia minima (Thompson, 1879) & - & Australia & Staples \& Watson (1987) \\
\hline Sertularella polyzonias Hartlaub, 1901 & - & - & Warren $(1908)^{*}$ \\
\hline Sertularia Linnaeus, 1758 & Anoplodactylus Wilson, 1878 & $\begin{array}{l}\text { Monterey Bay, } \\
\text { California }\end{array}$ & Russel \& Hedgpeth (1990) \\
\hline Sertularella Gray, 1848 & Unidentified pycnogonid larvae & South Africa & Warren $(1908)^{* *}$ \\
\hline Sertularella Gray, 1848 & Unidentified pycnogonid larvae & South Africa & Flynn $(1928) * *$ \\
\hline \multicolumn{4}{|l|}{ Campanulariidae Johnston, 1836} \\
\hline Ecopella everta (Clarck, 1896) & Ammothea hilgendorfi (Böhm, 1879) & & Russel \& Hedgpeth (1990) \\
\hline Clytia Lamouroux, 1812 & Anoplodactylus petiolatus (Kröyer, 1844) & & Russel \& Hedgpeth (1990) \\
\hline Obelia Péron \& Lesueur, 1810 & Anoplodactylus pygmaeus (Hodge, 1862) & - & Helfer $(1932)^{*}$ \\
\hline Obelia bidentata Clark, 1875 & Anoplodactylus Wilson, 1878 & Papua New Guinea & Staples \& Watson (1987) \\
\hline Campanularia australis Stechow, 1924 & - & Australia & Staples \& Watson (1987) \\
\hline Campanularia integra Macgillivray, 1842 & - & Australia & Staples \& Watson (1987) \\
\hline \multicolumn{4}{|l|}{ Plumulariidae Agassiz, 1862} \\
\hline Plumularia australis Kirchenpauer, 1876 & - & Australia & Staples \& Watson (1987) \\
\hline \multicolumn{4}{|l|}{ Subclasse Anthoathecata Cornelius, 1992} \\
\hline \multicolumn{4}{|l|}{ Tubulariidae Goldfuss, 1818} \\
\hline Tubularia crocea (Agassiz, 1862) & Anoplodactylus erectus Cole, 1904 & - & Frey \& Leuckart (1847)* \\
\hline Tubularia crocea (Agassiz, 1862) & Anoplodactylus erectus Cole, 1904 & - & Hilton $(1916)^{*}$ \\
\hline Tubularia Linnaeus, 1758 & Phoxichilidium tubulariae Lebour, 1945 & - & Loman (1907)* \\
\hline Tubularia larynx (Ellis \& Solander, 1786) & Phoxichilidium tubulariae Lebour, 1945 & $\begin{array}{l}\text { Gulf of Maine, New } \\
\text { Castle, USA }\end{array}$ & Lovely (2005) \\
\hline \multicolumn{4}{|l|}{ Corynidae Johnston, 1836} \\
\hline Sarsia eximia (Allman, 1859) & - & - & Allman (1860)* \\
\hline Sarsia eximia (Allman, 1859) & Phoxichilidium coccineum (Johnston, 1837) & - & Hodge $(1862)^{*}$ \\
\hline Sarsia radiata von Lendenfeld, 1884 & Anoplodactylus Wilson, 1878 & Australia & Staples \& Watson (1987) \\
\hline Coryne muscoides (Linnaeus, 1761) & Phoxichilidium virescens Hodge, 1864; & - & Staples \& Watson (1987) \\
\hline Coryne muscoides (Linnaeus, 1761) & Anoplodactylus pygmaeus (Hodge, 1862) & - & Staples \& Watson (1987) \\
\hline Coryne pusilla (Gaertner, 1774) & Anoplodactylus Wilson, 1878 & New Zealand & Staples \& Watson (1987) \\
\hline Coryne sp. & Amonthea sp. & - & Allman $(1860)^{* *}$ \\
\hline Coryne sp. & Anoplodactylus pygmaeus (Hodge, 1864) & - & Sanches $(1959)^{* *}$ \\
\hline Stylasteridae Gray, 1847 & Unidentified pycnogonid larva & - & Moseley $(1879)^{* *}$ \\
\hline \multicolumn{4}{|l|}{ Bougainvillidae Lüitken, 1850} \\
\hline Bougainvillia ramosa (van Beneden, 1844) & - & - & Van Beneden (1844)* \\
\hline Bougainvillia ramosa (van Beneden, 1844) & - & - & Gegenbaur $(1854)^{*}$ \\
\hline Bougainvillia ramosa (van Beneden, 1844) & Phoxichilidium virescens Hodge, 1864 & - & Staples \& Watson (1987) \\
\hline Bougainvillia ramosa (van Beneden, 1844) & Anoplodactylus pygmaeus (Hodge, 1862) & - & Staples \& Watson (1987) \\
\hline Bougainvillia Lesson, 1830 & Phoxichilidium Milne-Edwards, 1840 & - & Hallez $(1905)^{*}$ \\
\hline Bimeria vestita Wright, 1859 & Anoplodactylus petiolatus (Kröyer, 1844) & Mar del Plata, Argentina & Genzano (2002) \\
\hline Bougainvillia muscus (Allman, 1863) & Anoplodactylus petiolatus (Kröyer, 1844) & Mar del Plata, Argentina & Genzano (2002) \\
\hline \multicolumn{4}{|l|}{ Hydractiniidae L. Aggasiz, 1862} \\
\hline Podocoryne carnea (M. Sars, 1846) & Phoxichilidium virescens Hodge, 1864 & - & Staples \& Watson (1987) \\
\hline Podocoryne carnea (M. Sars, 1846) & Anoplodactylus pygmaeus (Hodge, 1862) & - & Staples \& Watson (1987) \\
\hline Hydractinia echinata Fleming, 1823 & - & - & Wright $(1863)^{*}$ \\
\hline Hydractinia echinata Fleming, 1823 & - & - & Semper $(1864)^{*}$ \\
\hline Hydractinia echinata Fleming, 1823 & - & - & Dohrn $(1881)^{*}$ \\
\hline Hydractinia echinata Fleming, 1823 & - & - & Dogiel $(1913)^{*}$ \\
\hline Hydractinia echinata Fleming, 1823 & - & - & Bourdillon (1952)* \\
\hline Hydractinia echinata Fleming, 1823 & Phoxichilidium virescens Hodge, 1864 & - & Staples \& Watson (1987) \\
\hline Hydractinia echinata Fleming, 1823 & Anoplodactylus pygmaeus (Hodge, 1862) & - & Staples \& Watson (1987) \\
\hline Hydractinia echinata Fleming, 1823 & Anoplodactylus petiolatus (Kröyer, 1844) & $\begin{array}{l}\text { Helgoland, } \\
\text { Deutschland, Germany }\end{array}$ & Heb \& Melzer (2003) \\
\hline
\end{tabular}

*References cited in Staples \& Watson (1987); **References cited in Bain (2003). 


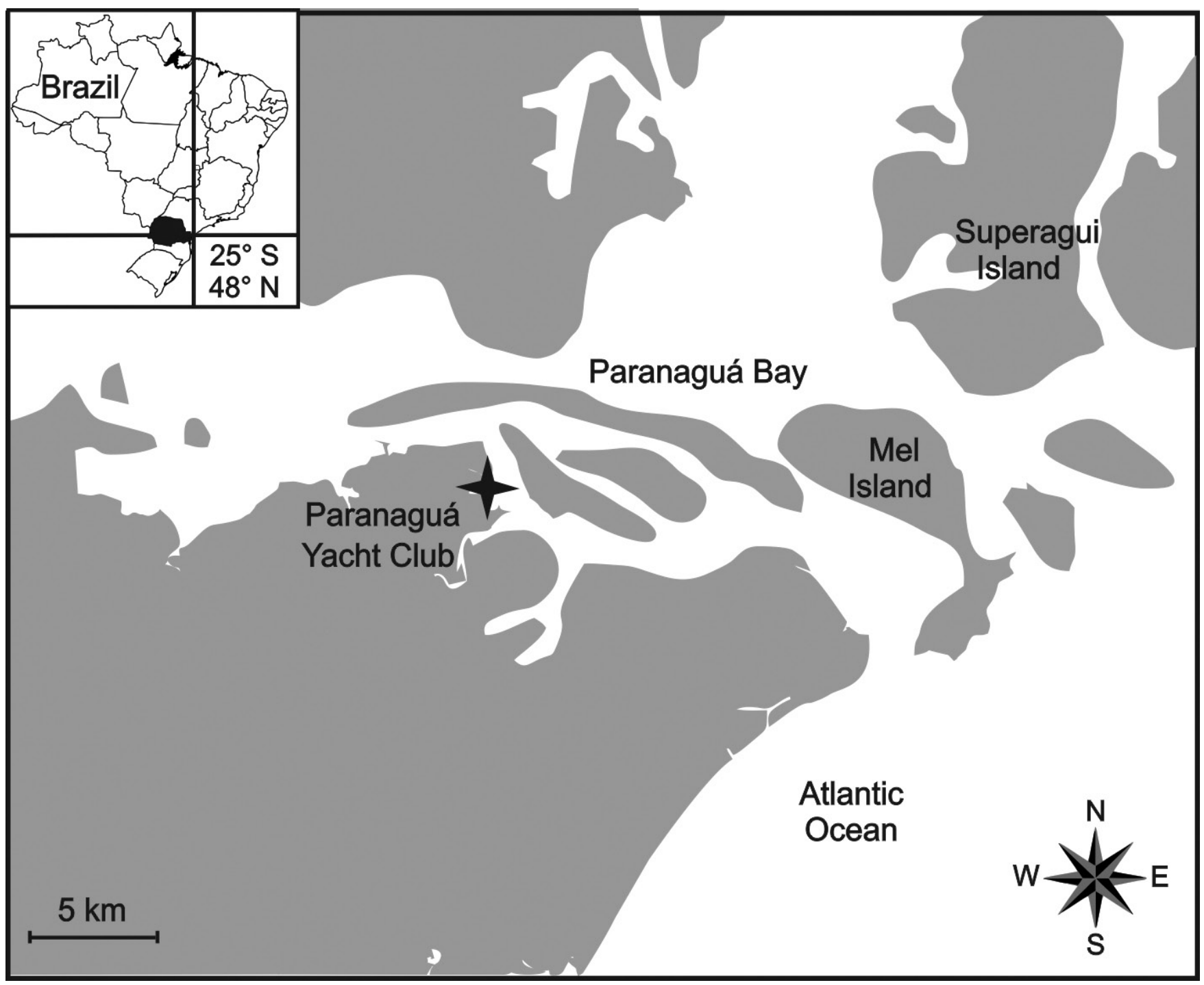

Figure 1. Location of the Paranaguá Yacht Club $\nmid$ inside Paranaguá Bay (where Podocoryna n. sp. was observed on the polyethylene plates) and Paraná State (dark area) in Brazil.

The degeneration began from the center of both colonies when the polyps decreased in size and lost their tentacles. The gallzooids (parasitized colony) quickly disappeared after the release of the juveniles, which became predators of the polyps. The gono- and tentaculozooids degenerated on the ninth day in the aquaria. The tentaculozooids of the parasitized colony remained active for longer. The gastrozooids degenerated gradually, and both colonies of Podocoryna n. sp. disappeared from the plates in one month (Figure 3). The desparasitized colony developed two stolons at its edge before total degeneration.

\section{Discussion}

How Pycnogonida larvae locate and penetrate gastrozooids has not yet been defined. Heb \& Melzer (2003) observed that when small specimens of the Pycnogonida Anoplodactylus petiolatus (Krøyer, 1844) Phoxichilidiidae walked on colonies of Hydractinia echinata (Fleming, 1828) Hydractiniidae, parts of or their entire body was retained inside the gastrovascular cavity of the gastrozooids. The captured individuals could escape without damage. This fact suggested that swallowed protonymphs could develop undamaged inside the gastrozooids (Heb \& Melzer 2003). Most likely, A. stictus has an immunity against Podocoryna n. sp. nematocysts and is unpalatable to the hydroid, as proposed by Heb \& Melzer (2003) for A. petiolatus. If endoparasitism depends on the ingestion of the larvae by gastrozooids, the absence of parasitized gono- and tentaculozooids in the Podocoryna n. sp. colonies is most likely because of the inability of these polyps to capture or swallow the protonymphs.

The Pycnogonida species that have an post-embryonic development with "encysted protonymphs" (see the review of Pycnogonida embryonic and post-embryonic development types in Brenneis et al. (2011a, b)) experience several molts inside the polyps. According to Bain (2003) and Lovely (2005), Pycnogonida hatch as juveniles in the fourth or fifth instar with a bud of walking leg 4 (Brenneis et al. 2011b), similar to the A. stictus that we observed in the aquaria. However, the hatching of $A$. stictus juveniles after the consumption of the gallzooid tissues of the Podocoryna n. sp. colonies contrasts with the report of Lovely (2005), who observed the parasite Phoxichilidium tubulariae Lebour, 1945 Phoxichilidiidae extending its legs to get rid of the gallzooids of Tubularia larynx Ellis \& Solander, 1786 Tubulariidae. 

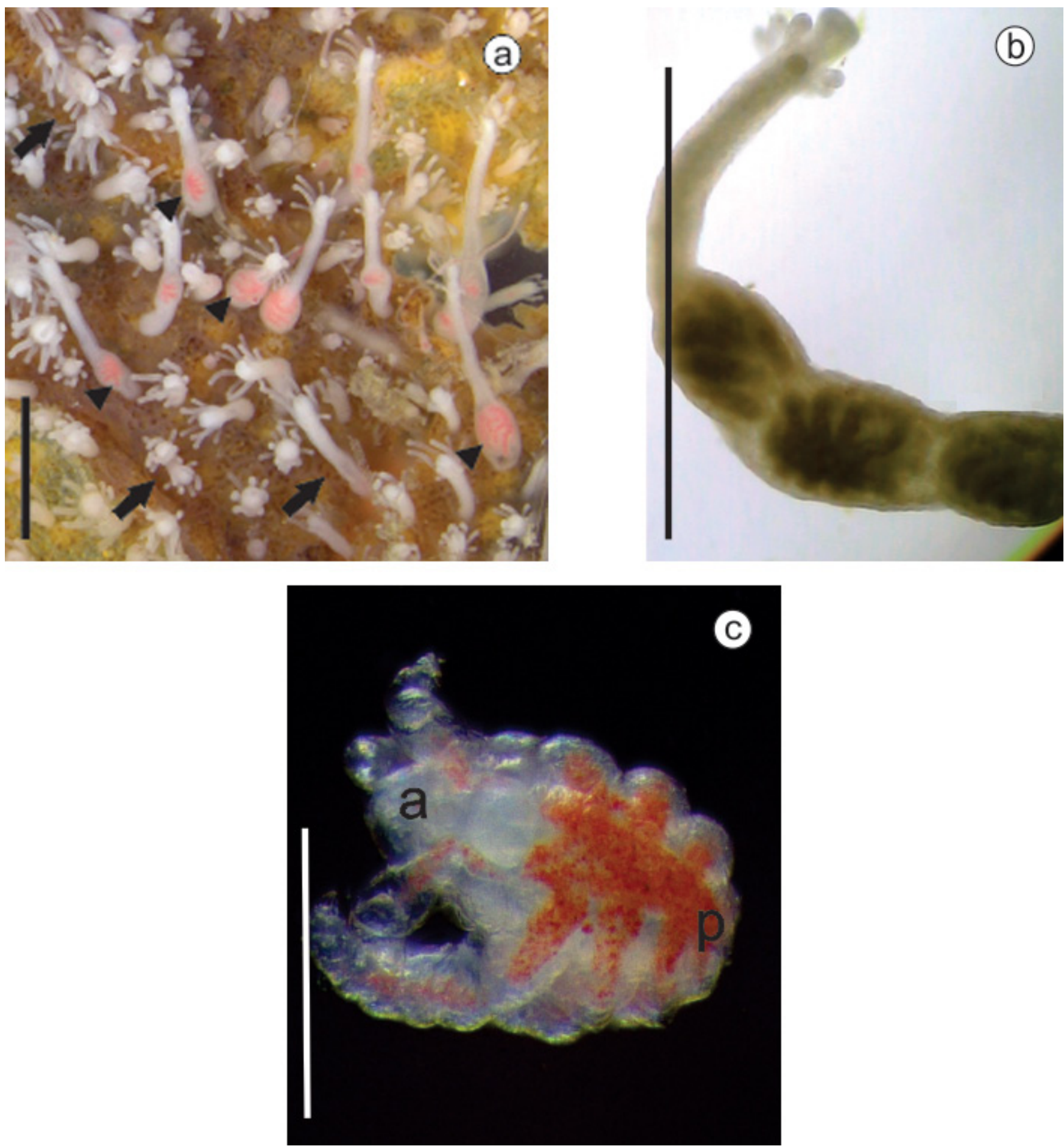

Figures 2. Larval endoparasitism of the Pycnogonida Anoplodactylus stictus in gastrozooids of the hydroid Podocoryna n. sp.: a) A portion of a Podocoryna n. sp. colony: the arrows indicate groups of gastrozooids, and the arrow heads indicate gallzooids; scale bar: $1 \mathrm{~cm} . ; \mathrm{b})$ An isolated gallzooid with tree protonymphs inside; scale bar: $0.1 \mathrm{~cm}$; c) Juvenile $A$. stictus newly released from inside a gallzooid: a - anterior, p - posterior; scale bar: $0.5 \mathrm{~cm}$. Photographs: (a, c) obtained with a Leica ${ }^{\circledR}$ MZ16 stereomicroscope with a Leica ${ }^{\circledR}$ DFC500 camera and processed in Auto-Montage Pro-3.5 Syncroscopy; (b) obtained with an Olympus ${ }^{\circledR}$ BX 51 optical microscope with an Olympus ${ }^{\circledR}$ America INC Oly-200 camera using the Honestech TVR 2.5 program.

The endoparasitic association between Pycnogonida and Cnidaria has been minimally investigated. The few studies regarding this association are mainly devoted to the description of the Pycnogonida life cycle (Russel \& Hedgpeth 1990, Genzano 2002, Lovely 2005); therefore, whether endoparasites affect the development or growth of the hydroid colony is not clarified. Both the parasitized and desparasitized colonies of Podocoryna n. sp. survived one month inside the aquaria, gradually degenerating simultaneously. We observed that the absence or reduced number of tentacles in the gallzooids did not compromise the nutrition of these polyps. In fact, the gastrozooids efficiently captured the brine shrimp nauplii and became orange-colored internally, which also occurred with 
Bettim, A.L. \& Haddad, M.A.

Table 2. Estimate of the area and composition of the Podocoryna n. sp. colonies at the beginning of the laboratory observations.

\begin{tabular}{lccccc}
\hline \multicolumn{1}{c}{ Colony } & Total area $\mathbf{c m}^{2}$ & \% gastrozooid & \% gonozooid & \% tentaculozooid & \% gallzooid \\
\hline Desparasitized & 16.3 & 75.3 & 7.6 & 5.1 \\
Parasitized & 8.8 & 67.2 & 0 & 12.0 & 17.2 \\
\hline
\end{tabular}

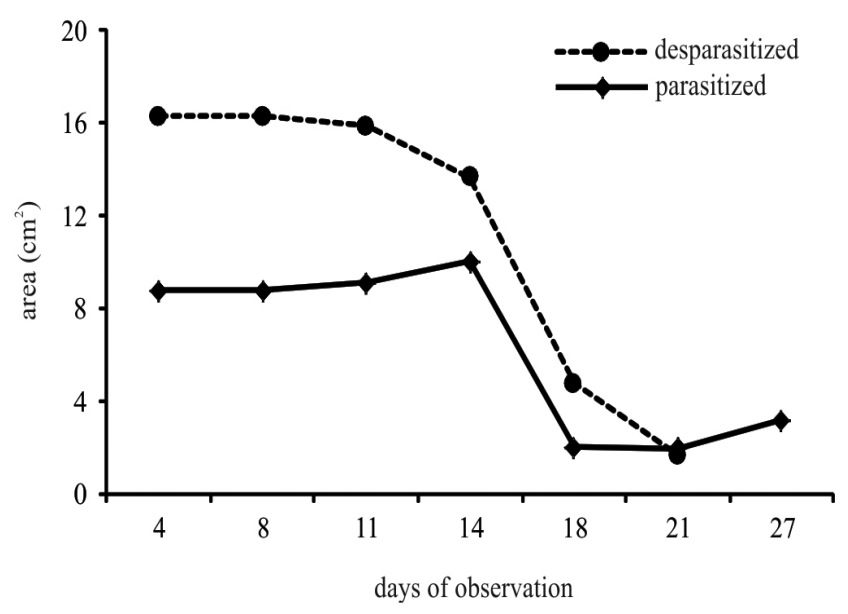

Figure 3. Variation of the Podocoryna n. sp. colony areas while maintained in the aquaria.

the gallzooids. The orange contents of the gallzooids indicated that if they could not catch the prey, they received food through the gastrovascular network.

Both the parasitized and desparasitized colonies of Podocoryna n. sp. possessed few gonozooids, signalizing they were about to complete their life cycle, and degeneration occurred in the natural process of their life span. When analyzing the succession of the encrusting community on the polyethylene plates from Paranaguá (pers. observ.), we observed that the parasitism by the A. stictus protonymphs mainly occurred in the larger and post-reproductive Podocoryna n. sp. colonies. After the period of parasitism, the colonies disappeared from the plates, similar to what occurred in the control colonies maintained in the aquaria. Therefore, although these preliminary observations of endoparasitism between $A$. stictus and Podocoryna n. sp. are not conclusive, they may suggest that the presence or absence of adult Pycnogonida on the colonies and small number of gallzooids most likely did not alter the survival time of the hydroid host.

\section{Acknowledgements}

We would like to thank the staff of the Paranaguá Yacht Club for kindly providing space for the study. We also thank Luciana Altvater, who conducted her master's dissertation at the Universidade Federal do Paraná and allowed the analysis of part of her data to be presented in this short communication. Ariane L. Bettim received a research grant from the CNPq.

\section{References}

ALTVATER, L. 2009. Composição e Sazonalidade de cnidários em substrato artifical, na Foz do Rio Itiberê, Baía de Paranaguá, Paraná. Tese de mestrado, Universidade Federal do Paraná, Curitiba.

BAIN, B.A. 2003. Larval types and a summary of postembryonic development within the pycnogonids. Invertebr. Reprod. Dev. 43(3):193-22. http:// dx.doi.org/10.1080/07924259.2003.9652540
BAVESTRELLO, G., CERRANO, C., CATTANEO-VIETTI, R. \& SARÀ, M. 1996. Relations between Eudendrium glomeratum (Cnidaria, Hydromedusae) and its associated vagile fauna. Sci. Mar. 60(1):137-143.

BAVESTRELLO, G., PUCE, S., CERRANO, C. \& BALDUZZI, A. 2000. Life history of Perarella schneideri (Hydrozoa, Cytaedidae) in the Ligurian Sea. Sci. Mar. 64(1):141-146.

BOERO, F., BOUILLON, J. \& GRAVILI, C. 1991. The life cycle of Hydrichthys mirus (Cnidaria: Hydrozoa: Anthomedusae: Pandeidae). Zool. J. Linn. Soc-Lond. 101:189-199. http://dx.doi.org/10.1111/j.1096-3642.1991. tb00893.x

BOERO, F. \& BOUILLON, J. 2005. Cnidaria and Ctenophora. In: Marine Parasitology (K. Rhode, ed.). CSIRO Publishing, Australia, p.177-182.

BRAVERMAN, M.H. 1960. Differentiation and commensalism in Podocoryne carnea. Am. Midl. Nat. 63(1):223-225. http://dx.doi.org/10.2307/2422942

BRENNEIS, G., ARANGO, C.P. \& SCHOLTZ, G. 2011a. Morphogenesis of Pseudopallene sp. (Pycnogonida, Callipallenidae) I: embryonic development. Dev. Genes. Evol. 221:309-328. http://dx.doi.org/10.1007/ s00427-011-0382-4

BRENNEIS, G., ARANGO, C.P. \& SCHOLTZ, G. 2011b. Morphogenesis of Pseudopallene sp. (Pycnogonida, Callipallenidae) II: postembryonic development. Dev. Genes. Evol. 221:329-350. http://dx.doi.org/10.1007/ s00427-011-0381-5

CAINE, E.A. 1998. First case of caprellid Amphipod-Hydrozoan mutualism. J. Crustacean Biol. 18(2):317-320. http://dx.doi.org/10.2307/1549325

CANGUSSU, L.C., ALTVATER, L., HADDAD, M.A., CABRAL, A.C., HEYSE, H.L. \& ROCHA, R.M. 2010. Substrate type as a selective tool against colonization by non-native sessile invertebrates. Braz. J. Oceanogr. 58(3):219-231. http://dx.doi.org/10.1590/S167987592010000300005

CERrano, C., BAVESTREllo, G., PUCE, S. \& SARÀ, M. 1998. Biological Cycle of Podocoryna exigua (Cnidaria: Hydrozoa) from a Sandy Bottom of the Ligurian Sea. J. Mar. Biol. Assoc. Uk. 78(4):11011111. http://dx.doi.org/10.1017/S0025315400044350

CERRANO, C., PUCE, S., CHIANTORE, M. \& BAVESTRELLO, G. 2000. Unusual trophic strategies of Hydractinia angusta (Cnidaria, Hydrozoa) from Terra Nova Bay, Antarctica. Polar Biol. 23: 488-494. http://dx.doi. org/10.1007/s003000000110

Cerrano, C., PUCE, S., Chiantore, M., BAVESTrello, G. \& CATTANEO-VIETTI, R. 2001. The influence of the epizoic hydroid Hydractinia angusta on the recruitment of the Antarctic scallop Adamussium colbecki. Polar Biol. 24:577-581. http://dx.doi.org/10.1007/ s003000100254

CORREIA, M.D. \& SILVA, J.L. 1990. Caracterização das comunidades incrustantes e a fauna associada em painéis experimentais na Baía de Paranaguá, Paraná, Brasil. In: II Simpósio de Ecossistemas da Costa Sul e Sudeste Brasileira: Estrutura, Função e Manejo. Academia de Ciências do Estado de São Paulo, São Paulo, p.89-110.

CUNHA, A.F. \& JACOBUCCI, G.B. 2010. Seasonal variation of epiphytic hydroids (Cnidaria: Hydrozoa) associated to a subtropical Sargassum cymosum (Phaeophyta: Fucales) bed. Zoologia. 27(6):945-955. http:// dx.doi.org/10.1590/S1984-46702010000600016

EVANS, N.M., LINDNER, A., RAIKOVA, E.V., COLLINS, A.G. \& CARTWRIGHT, P. 2008. Phylogenetic placement of the enigmatic parasite, Polypodium hydriforme, within the Phylum Cnidaria. BMC Evol. Bio. 8:139.

GENZANO, G.N. 2002. Associations between pycnogonids and hydroids from the Buenos Aires littoral zone, with observations on the semi-parasitic life cycle of Tanystylum orbiculare (Ammotheiidae). Sci. Mar. 66(1):83-92.

GENZANO, G.N. \& SAN MARTIN, G. 2002. Association between the polychaete Procerastea halleziana (Polychaeta: Syllidae: Autolytinae) and the hydroid Tubularia crocea (Cnidaria: Hydrozoa) from the Mar del Plata intertidal zone, Argentina. Cah. Biol. Mar. 43(2):165-170. 
GILI, J.-M. \& HUGHES, R.G. 1995. The Ecology of marine benthic hydroids. Oceanogr. Mar. Biol. 33(4):351-426.

GILI, J.-M., LÓPEZ-GONZÁLEZ, P.J. \& BOUILLON, J. 2006. A new Antarctic association: the case of the hydroid Sarsia medelae (new sp.) associated with gorgonians. Polar Biol. 29(7):624-631. http://dx.doi. org/10.1007/s00300-005-0098-x

HADDAD, M.A. \& MARQUES, A.C. 2009. Cnidaria. In Estado da arte e perspectivas para a Zoologia no Brasil. (R.M. Rocha \& W.A.P. Boeger eds). Editora UFPR, Curitiba, p.29-48.

HAND, C. \& HENDRICKSON, J.R. 1950. A two-tentacled, commensal hydroid from California (Limnomedusae, Proboscidactyla). Biol. Bull. 99(1):74-87. http://dx.doi.org/10.2307/1538753

HEB, M. \& MELZER, R.R. 2003. Anoplodactylus petiolatus (Pycnogonida) and Hydractinia echinata (Hydrozoa) - Observations on galls, feeding behaviour and hot's defence. Vie Milieu. 53(2-3):135-138.

LOVELY, E.C. 2005. The Life History of Phoxichilidium tubulariae (Pycnogonida: Phoxichilidiidae). Northeast. Nat. 12(1):77-92. http:// dx.doi.org/10.1656/1092-6194(2005)012[0077:TLHOPT]2.0.CO;2

MADIN, L.P., BOLLENS, S.M., HORGAN, E., BUTLER, M., RUNGE, J., SULLIVAN, B.K., KLEIN-MACPHEE, G., DURBIN, E., DURBIN, A., VANKEUREN, D. 1996. Voracious planktonic hydroids: unexpected predatory impact on a coastal marine ecosystem. Deep-Sea Res. Pt. II. 43(7-8):1823-1829. http://dx.doi.org/10.1016/S0967-0645(96)00038-0

MARCUS, E. 1940. Os pantopodas brasileiros e os demais sul americanos. Bol. Facult. Filos. Ciên. Letr. 19(Zoologia 4):3-179.

MIGOTTO, A.E., SILVEIRA, F.L., SCHLENZ, E. \& FREITAS, J.C. 1999. Filo Cnidaria. In: Bases para conservação da biodiversidade de São Paulo - Síntese do conhecimento ao final do século XX 3: invertebrados marinhos. (A.E. Migotto \& C.G. Tiago, eds). FAPESP, São Paulo, p.33-46.

MORANDINI, A.C., MARTORELLI, S.R., MARQUES, A.C. \& SILVEIRA, F.L. 2005. Digenean metacercaria (Trematoda, Digenea, Lepocreadiidae) parasitizing "coelenterates" (Cnidaria, Scyphozoa and Ctenophora) from Southeastern Brazil. Braz. J. Oceanogr. 53(1-2):39-45. http://dx.doi. org/10.1590/S1679-87592005000100004

NEVES, C.S. \& ROCHA, R.M. 2008. Introduced and cryptogenic species and their management in Paranaguá Bay, Brazil. Braz. Arch. Biol. Techn. 51(3):623-633. http://dx.doi.org/10.1590/S151689132008000300025
NEVES, C.S., ROCHA, R.M., PITOMBO, F.B. \& ROPER, J.J. 2007. Use of artificial substrata by introduced and cryptogenic marine species in Paranaguá Bay, southern Brazil. Biofouling. 23(5-6):319-30. http://dx.doi. org/10.1080/08927010701399174

NOGUEIRA JUNIOR, M. \& SILVA, J.L. 2005. Associações entre medusas (Cnidaria) e isópodos (Crustacea) nos litorais do Paraná e Santa Catarina, Brasil. Acta Biol. Par. 34 (1-2-3-4):127-138.

PIRAINO, S., BOUILLON, J. \& BOERO, F. 1992. Halocoryne epizoica (Cnidaria, Hydrozoa), a hydroid that "bites." Sci. Mar. 56(2-3):141-147.

PUCE, S., CERRANO, C., DI CAMILlO, C.G. \& BAVESTRELlO, G. 2008. Hydroidomedusae (Cnidaria: Hydrozoa) symbiotic radiation. J. Mar. Biol. Assoc. Uk. 88(8):1715-1721. http://dx.doi.org/10.1017/ S0025315408002233

RASKOFF, K.A. \& ROBISON, B.H. 2005. A novel mutualistic relationship between a doliolid and a cnidarian, Bythotiara dolioeques sp. nov. J. Mar. Biol. Assoc. Uk. 85:583-593. http://dx.doi.org/10.1017/ S0025315405011513

RHODE, K. 2005. Marine Parasitology. CSIRO Publishing, Australia.

RUSSEL, D.J. \& HEDGPETH, J.W. 1990. Host utilization during ontogeny by two pycnogonid species (Tanystylum duospinum and Ammothea hilgendorfi) parasitic on the hydroid Eucopella everta. Bijdr. Dierkd. 60(3-4):215-224.

SILVEIRA, F.L. \& MORANDINI, A.C. Checklist dos Cnidaria do Estado de São Paulo, Brasil. Biota Neotrop. 11(1a):http://www.biotaneotropica. org.br/v11n1a/pt/abstract?inventory+bn0161101a2011 (último acesso em 07/07/12).

STAPLES, D. 2005. Pycnogonida. In: Marine Parasitology (K. Rhode, ed.). CSIRO Publishing, Australia, p.177-182.

STAPLES, D.A. \& WATSON, J.E. 1987. Associations between pycnogonids and hydroids. In Modern Trends in the Systematics, Ecology and Evolution of Hydroids and Hydromedusae (Oxford Science Publications) (J. Bouillon, F. Boero, F. Cicogna \& P.F.S. Cornelius, eds.). Oxford University Press, United States of America, p.215-226.

VAN OFWEGEN, L.P. \& HADDAD, M.A. 2011. A probably invasive new genus and new species of soft coral (Octocorallia: Alcyonacea: Clavulariidae) from Brazil. Zootaxa. 3107:38-46.

WORMS. WoRMS taxon details. http://www.marinespecies.org/aphia. php?p=taxdetails\&id=1267 (último acesso em 23/08/2012). 